\title{
A new cuticle scale hydrolysing protease from Beauveria brongniartii
}

\author{
A. Erlacher $\cdot$ F. Sousa $\cdot$ M. Schroeder $\cdot$ \\ S. Jus · V. Kokol · A. Cavaco-Paulo • \\ G. M. Guebitz
}

Received: 15 November 2005 / Accepted: 9 January 2006/Published online: 23 May 2006

(C) Springer Science+Business Media B.V. 2006

\begin{abstract}
From a screening for the production of new proteases specific for cuticle scales, Beauveria brongniartii was selected producing an alkaline $\mathrm{Ca}^{++}$dependent protease. The purified had a molecular weight of $27 \mathrm{kDa}$ and a pI value of 8.0. Substrate specificities of model substrates (wool with partially removed cuticles treated with SDS) were analyzed by protein release, dissolved organic carbon (DOC) and nitrogen analysis. The $\mathrm{C} / \mathrm{N}$ ratio of released material turned out to be a good parameter to determine the site of action of proteases on fibres. Compared to other enzymes, the fungal protease preferentially hydrolyzed cuticle scales and has thus a potential for antishrinking pre-treatment of wool fabrics.
\end{abstract}

Keywords Wool Cuticle $\cdot$ Protease Beauveria brongniartii

A. Erlacher · F. Sousa · M. Schroeder ·

G. M. Guebitz $(\bowtie)$

Department of Environmental Biotechnology, Graz University of Technology, Petersgasse 12, Graz, Austria

e-mail: guebitz@tugraz.at

S. Jus · V. Kokol

Textile Department, University of Maribor, Maribor, Slovenia

\section{A. Cavaco-Paulo}

Department of Textile Engineering, University of Minho, Guimaraes, Portugal

\section{Introduction}

Wool contributes to the world textile fibre production with only $1 \%$, however, due to its special garment-physiological properties and the vast possibilities of processing and finishing methods it is an important raw material for the textile industry (Zahn et al. 1997). Almost all types of woven and knitted wool products will shrink in absence of any preventative treatments. Felting is the common term for the progressive fibre entanglement of wool products subjected to mechanical action (mainly during laundering). Primarily responsible for felting is the cuticle or scale cell structure when the overlapping cells are tightly stuck to each other and to the underlying cortex (Simpson and Crawshaw 2002). Antifelting treatments are usually based on partial removal, softening or uniform coating of the cuticle scales. For ecological reasons, work is directed to new antifelting processes to avoid the use of chlorine or chlorine compounds used e.g. in the Chlorine/ Hercosett process. Furthermore, treatments retaining the natural properties of wool would be preferable compared to coating with synthetic materials.

Enzymatic processes have been suggested as an alternative pre-treatment meeting these requirements (Zahn and Hoffmann 1996). Wool properties like handle, lustre and whiteness have been reported to be enhanced by enzyme-catalyzed 
reactions (Heine and Höcker 1995; El-Sayed et al. 2001) described the use of the protease papain on pre-treated wool (lipase/sodium monoperoxyphthalate/sodium sulphite) resulting in a shrink-proofed effect. A commercial enzyme preparation combined with an alkaline peroxide treatment followed by application of chitosan biopolymer showed good effects concerning shrink resistance of wool, moreover the wettability and whiteness were enhanced (Jovancic et al. 2001, 2003) showed that during enzymatic treatments the F-layer of wool was completely removed and the content of cysteic acid was significantly decreased whereas during plasma treatment a partial oxidation of hydrocarbon chains of the F-layer and the formation of cysteic acid residues at the wool surface was detected.

Despite the promising results of proteasebased pre-treatment processes of wool, partial damage of the fibres by the proteases still remains a major problem. While the use other enzymes such as protein-cross linking enzymes (transglutaminases) has been recently suggested to avoid this risk associated with proteases, other promising approaches involve chemical modification of proteases (Schroeder et al. 2004). Finally, the screening for new proteases with high specificity to cuticles could be an interesting alternative to existing enzymes.

In this study, a new protease with higher specificity to the outer part of wool fibres than bacterial proteases was isolated from Beauveria brongniartii. This enthomopathogenic fungus is mainly used as a biocontrol agent against the May beetle (Koller et al. 2005) and longicorn beetles (Higuchi et al. 1997).

\section{Materials and methods}

Screening and cultivation of microorganisms

A total of nine fungal strains deposited at the culture collection of the Department of Environmental Biotechnology, Graz University of Technology, Austria were screened for their ability to degrade wool cuticle scales: Aspergillus tereus A9, Bjerkandera adusta BAG1, Penicillium simplicissimum, Trichoderma viride BJG 102,
Aspergillus niger, Curvularia lunata IT 0005, Beauveria brongniartii, Fusarium solanii VAI 1 and Cylindrocarpon radicicola DSM 837. The fungi were usually grown on pepton glucose Agar (Fluka, Buchs, Switzerland) plates at $30^{\circ} \mathrm{C}$ for 3-7 days and stored at $4^{\circ} \mathrm{C}$ thereafter. The medium for production of proteases consisted of $10 \mathrm{~g}$ wool or wheat bran flakes $\mathrm{L}^{-1}, 4 \mathrm{~g} \mathrm{MgSO}_{4} \cdot 7 \mathrm{H}_{2} \mathrm{O}$

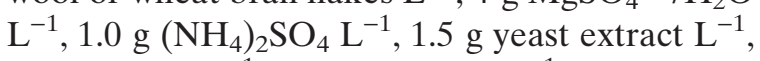
$5 \mathrm{~g} \mathrm{KH}_{2} \mathrm{PO}_{4} \mathrm{~L}^{-1}$ and $1 \mathrm{~g}$ glucose $\mathrm{L}^{-1}$. The $\mathrm{pH}$ was adjusted to 4.0. All chemicals were obtained from Sigma. For cultivation of the fungi $250 \mathrm{ml}$ of this medium in Erlenmeyer flasks $(500 \mathrm{ml})$ were inoculated with $1 \mathrm{~cm}^{2}$ of the actively growing fungus from PDA-plate and incubated $30^{\circ} \mathrm{C}$ on a rotary shaker $(160 \mathrm{rpm})$. Growth was monitored by daily measurement of the protease activity using azocasein as substrate. Every few days the $\mathrm{pH}$ was controlled and the broth was observed for possible infections under the microscope. Cultures were harvested by centrifugation (10 min at $9,500 \mathrm{~g})$.

Before addition to the cultivation medium $20 \mathrm{~g}$ of raw wool (Drummond Parkland of England, Huddersfield, UK) were washed in $800 \mathrm{ml} \mathrm{H}_{2} \mathrm{O}$ (pH 9.0) containing $0.80 \mathrm{~g}$ Lutensol ${ }^{\circledR}$ A $7 \mathrm{~N}$ (BASF), $1.34 \mathrm{~g} \mathrm{NaHCO}_{3}$ and $15.12 \mathrm{~g} \mathrm{Na}_{2} \mathrm{SO}_{3}$. The reaction mixture was shaken at $60^{\circ} \mathrm{C}$ in a waterbath for $30 \mathrm{~min}$.

Protease activity with azocasein

Two hundred and fifty microlitre of $2 \%(\mathrm{w} / \mathrm{v})$ azocasein solution in $50 \mathrm{mM}$ Tris $\mathrm{HCl}$ buffer $(\mathrm{pH}$ 8.0) were equilibrated in a thermomixer comfort (Eppendorf, Hamburg, Germany) at $37^{\circ} \mathrm{C}$. The reaction was initiated by pipetting $150 \mu \mathrm{l}$ sample to the substrate. The mixture was incubated at $37^{\circ} \mathrm{C}$ for $30 \mathrm{~min}$ and the reaction was stopped by addition of $1.2 \mathrm{ml}$ of $10 \%(\mathrm{w} / \mathrm{v})$ trichloroacetic acid (TCA). The samples were shaken for a short time and allowed to stand at room temperature for $15 \mathrm{~min}$ to ensure complete precipitation of the remaining azoprotein and azoprotein fragments. Thereafter, the samples were centrifuged at $9,500 \mathrm{~g}$ for $3 \mathrm{~min}$ and $600 \mu \mathrm{l}$ of the clear supernatant were transferred to a cuvette containing $700 \mu \mathrm{l}$ of $1.0 \mathrm{M} \mathrm{NaOH}$. The absorbance was read at $440 \mathrm{~nm}$ with a spectrophotometer (Kontron, 
Uvikon 940, München, Germany). One unit of protease activity is defined to be the amount of enzyme required to produce an absorbance change of 1.0 in a $1 \mathrm{~cm}$ cuvette under the conditions of the assay.

\section{Enzyme purification}

The fermentation broth containing the wool substrate was filtered with a sieve to separate the wool from the medium. The resulting solution was centrifuged at $13,700 \mathrm{~g}$ with a Sorvall ${ }^{\circledR}$ RC-5B Refridgerated Superspeed Centrifuge (DuPont Instruments, Wilmington, USA) at a temperature of $10^{\circ} \mathrm{C}$ for $20 \mathrm{~min}$. The supernatant was collected, filtered and aliquots were stored at $-20^{\circ} \mathrm{C}$ until further processing.

Defrosted samples were filtered through a $0.2 \mu \mathrm{m}$ Whatman filter via pressure filtration to eliminate the precipitated polysaccharides and to obtain a clear solution. After centrifugation, the culture supernatant was desalted $(3 \mathrm{x}$ washing with buffer containing $20 \mathrm{mM} \mathrm{CaCl}$ ) and concentrated by ultrafiltration with VivaSpin 20 (Vivascience, Hannover, Germany), equipped with polyethersulphone membranes with a $5 \mathrm{kDa}$ cut off at 3,000 g. All chromatographic purification steps were carried out using an Aekta Purifier FPLC system from Amersham Pharmacia Biotech. As a first step a cation exchange column HiTrap ${ }^{\mathrm{TM}}$ SP HP (Amersham Biosciences, Uppsala, Sweden), pH 7.5 (50 mM HEPES; for elution $1 \mathrm{M} \mathrm{NaCl}$ was added) was chosen. $100 \mu \mathrm{l}$ of sample were applied to the column ( $1 \mathrm{ml}$ column volume) at a flow rate of $1 \mathrm{ml} \mathrm{min}{ }^{-1}$. Fractions with a volume of $1 \mathrm{ml}$ were collected.

For size exclusion chromatography, the concentrated pooled fractions from cation exchange chromatography $(100 \mu \mathrm{l})$ were subjected to a Superdex 75 HR 10/30 with a fractionation range from 3 to $70 \mathrm{kDa}$ (Amersham Pharmacia Biotech) which was equilibrated with phosphate buffer $(0.1 \mathrm{M}) \mathrm{pH} 8.0$ containing $0.1 \mathrm{M} \mathrm{NaCl}$. The column was run with the same buffer with a flow rate of $0.5 \mathrm{ml} \mathrm{min}^{-1}$. All desalting and concentration steps were done using ultrafiltration (VivaSpin 20) with $5 \mathrm{kDa}$ cut off at $3,000 \mathrm{~g}$ as described above.

\section{Characterization}

In order to study the $\mathrm{pH}$ stability of the Beauveria brongniartii protease, enzyme samples (47 ng enzyme protein $\mathrm{mL}^{-1}$ ) were incubated at various $\mathrm{pH}$ values between $\mathrm{pH} 4$ and $\mathrm{pH} 10$ (Britton Robinson buffer) at room temperature. Residual enzyme activity was measured using the standard azocasein assay procedure. Temperature stabilities $\left(20-60^{\circ} \mathrm{C}\right)$ were measured similarly using $50 \mathrm{mM}$ Tris- $\mathrm{HCl}$ buffer, $\mathrm{pH}$ 8.0. The reaction was started by incubating $1.47 \mathrm{ml}$ of buffer with $30 \mu \mathrm{l}$ enzyme solution. Common protease inhibitors were tested for their effect on the activity of the $B$. brongniartii protease. $20 \mu \mathrm{l}$ of the protease were pre-incubated with varying amounts of inhibitorsolution and $50 \mathrm{mM}$ Tris- $\mathrm{HCl}$ buffer, $\mathrm{pH} 8$ for different time intervals in a final volume of $1 \mathrm{ml}$ at room temperature. The final concentration of inhibitor was $1.46 \mu \mathrm{M}$ for Pepstatin $\mathrm{A}, 10 \mu \mathrm{M}$ for E-64, $0.3 \mu \mathrm{M}$ for Aprotinin and $1 \mathrm{mM}$ for EDTA. Additionally, the effect of the double charged ions $\mathrm{Ca}^{2^{+}}, \mathrm{Mg}^{2^{+}}, \mathrm{Mn}^{2^{+}}, \mathrm{Zn}^{2^{+}}, \mathrm{Cu}^{2^{+}}$was assessed at a concentration of $5 \mathrm{mM}$ in $50 \mathrm{mM}$ Tris- $\mathrm{HCl}$ buffer $\mathrm{pH} 8.0$ incubated for different time intervals at room temperature. The effect of $\mathrm{CaCl}_{2}$ was assessed at 5, 10, 20, 30, 50 and $100 \mathrm{mM}$ concentration. Different organic solvents (DMSO, DMF, $\mathrm{MeOH}, \mathrm{EtOH}, \mathrm{ACN}$ and isopropanol) were tested on their effect to the isolated enzyme while incubating at $37^{\circ} \mathrm{C}$ for certain times. Deglycosilation was performed with the endoglycosidase Endo H P0702 L (New England Biolabs, Ipswich, USA). Its activity was $500,000 \mathrm{U} \mathrm{ml}^{-1}$ and the molecular weight was $29 \mathrm{kDa} .27 \mu \mathrm{l}$ of the purified enzyme were mixed with $3 \mu$ denaturation buffer (5\% SDS, $10 \% \beta$-mercaptoethanol) and heated at $100^{\circ} \mathrm{C}$ for $5 \mathrm{~min}$.

To $8.25 \mu \mathrm{l}$ of the denaturated sample $1 \mu \mathrm{l} 1 / 10$ G5 buffer (sodium citrate, $\mathrm{pH}$ 5.5) was added. The reaction was started by adding $0.75 \mu \mathrm{l}$ Endo $\mathrm{H}$ and was performed at $37^{\circ} \mathrm{C}$ over night. After the incubation time samples were run on a SDS gel and further on silver stained.

The 1D SDS gels were performed according to Laemmli and the 2D gel was operated according to the Amersham method. Isoelectric focusing (IEF) was performed on 5\% polyacrylamide gels with a thickness of $1 \mathrm{~mm}$ and a $\mathrm{pH}$ gradient from 
3 to 10. IEF gels were stained with Coomassie brilliant blue R-250.

Substrate specificities of the B. brongniartii protease

Hydrolytic activity of the enzyme with $p$-nitroanilide ( $p$ NA) and ester substrates was tested at $30^{\circ} \mathrm{C}$ in $50 \mathrm{mM}$ Tris- $\mathrm{HCl}$ buffer, $\mathrm{pH}$ 8.0. The substrates used were N-Suc-Ala-Ala-Pro-Phe$p$ NA, N-Suc-Ala-Ala-Pro-Leu- $p$ NA, L-Leucine$p \mathrm{NA}$ and Gly-Phe-pNA. All tested substrates were purchased from Sigma (St. Louis, USA). The release of $p$ NA was measured at $410 \mathrm{~nm}$ $\left(\epsilon=8,480 \mathrm{M}^{-1} \mathrm{~cm}^{-1}\right.$ (Bakhtiar et al. 2005)). Initial reaction rates were determined at different substrate concentrations and kinetic parameters were calculate by non-linear regression using the program Origin 5.0. Stock solutions were prepared in DMSO $(4 \mathrm{mM})$ and further dilutions were done with buffer.

Digest and MS-analysis

Bands of interest were cut out of a SDS gel and the tryptic in-gel-digest was optimized following the procedure after Shevchenko et al. (1996). MS analysis was performed using a nanoHPLC-ESIIonTrap instrument from Agilent. For HPLC separation a multistep-gradient was run from $100 \%$ A (water with $0.1 \%$ formic acid) to $95 \%$ B (ACN with $0.1 \%$ formic acid) within $80 \mathrm{~min}$. The flow was maintained at $300 \mathrm{nl} \mathrm{min}{ }^{-1}$. The enrichment column was a ZORBAX SB-C18, $5 \times 3 \mathrm{~mm}$ (Agilent) and as separation column a ZORBAX 300SB-C18, $3.5 \mu \mathrm{m}, 50 \times 0.075 \mathrm{~mm}$ (Agilent) was used. The injection volume was $10 \mu \mathrm{L}$.

Spectra were obtained with an ion trap mass spectrometer (Agilent 1100 series LC/MSD Trap, Agilent, Waldbronn, Germany). The spray voltage was set to $1.1 \mathrm{kDa}$ and the capillary temperature was set to $100^{\circ} \mathrm{C}$. Dry gas was set to $6.001 \mathrm{~min}^{-1}$, the accumulation time was $50 \mathrm{~ms}$ and the spectra were obtained by scanning a range from 200 to $2200 \mathrm{~m} / \mathrm{z}$. The spectrum was acquired with the Auto MS (2) mode. The compound mass spectra were analyzed using the database program MASCOT (MatricScience
LTD, Boston, USA) choosing the NCBInr database (NCBI Resources, Bethesda, USA).

Wool treatment

Raw wool was obtained from Drummond Parkland of England, (Huddersfield, UK). To obtain wool fibres with partially removed cuticles, the method of Ley (1988) was adapted. To $5 \mathrm{~g}$ of washed wool (cut with scissors into small pieces) $250 \mathrm{ml} 0.1 \%$ SDS (w/v) solution was added and removal of cuticles was monitored microscopically (Laborlux S, Leitz, Oberkochen, Germany). The mixture was shaken at $27^{\circ} \mathrm{C}$. After $42 \mathrm{~h}$ of incubation, the reaction was stopped by washing the wool with plenty of demineralised water. The effect of detergent on wool was observed with a brightfield light microscope.

Alternatively, $5 \mathrm{~g}$ of washed wool snippets were transferred to $200 \mathrm{ml}$ of formic acid (100\%) and heated at $100^{\circ} \mathrm{C}$ for $1 \mathrm{~h}$ (Bradbury 1970). Then the wool was washed with plenty of water and the $\mathrm{pH}$ of water and wool was monitored. The effect of formic acid on wool was observed by light microscopy. Hydrolysis of these wool substrates was studied both with the isolated $B$. brongniartii protease and a bacterial protease from Bacillus sp. (Sousa et al. 2005).

Enzyme treatment of native and pre-treated wool was started by adding a defined activity of protease $\left(10 \mathrm{mU} \mathrm{min}{ }^{-1}\right)$ to $0.5 \mathrm{~g}$ washed wool in $50 \mathrm{ml}$ of $50 \mathrm{mM}$ borate buffer with $20 \mathrm{mM}$ $\mathrm{CaCl}_{2}$ (only for $B$. brongniartii protease) in $100 \mathrm{ml}$ Erlenmeyer flasks. Incubation was carried out at $37^{\circ} \mathrm{C}$ with shaking at $150 \mathrm{rpm}$. As blanks the enzyme alone and wool without enzyme were incubated. $5 \mathrm{ml}$ samples were taken in certain time intervals protease activity was immediately determined to follow the stability of the enzyme during the reaction. Thereafter, samples was denaturated in a water bath at $100^{\circ} \mathrm{C}$ for $5 \mathrm{~min}$ and stored at room temperature until the measurement of $\mathrm{C}$ and $\mathrm{N}$-Content (dissolved organic carbon (DOC), TN; TOCVCPH Total carbon analyzer, equipped with an ASI-V autosampler and a TNM-1 Total measuring unit from Shimadzu (Kyoto, Japan) and protein absorption (Biophotometer, Eppendorf $280 \mathrm{~nm}$ ). 


\section{Results and discussion}

\section{Screening}

To isolate proteases with high specificity to wool cuticles nine different fungi (see Materials and methods) were tested for their ability to produce such enzymes with wool as carbon source. Out of these fungi Beauveria brongniartii showed best results in producing proteases when grown on wool. In Fig. 1 protease activity produced by $B$. brongniartii when grown on wool is shown.

Enzyme purification and characterisation

Concentration of $B$. brongniartii wool protease was performed by ultrafiltration $(5 \mathrm{kDa})$ including three washes of in the presence of $20 \mathrm{mM}$ $\mathrm{CaCl}_{2}$. The loss of activity was only $6 \%$ with the optimized method which was quite reasonable as first concentration step. Cation exchange chro-

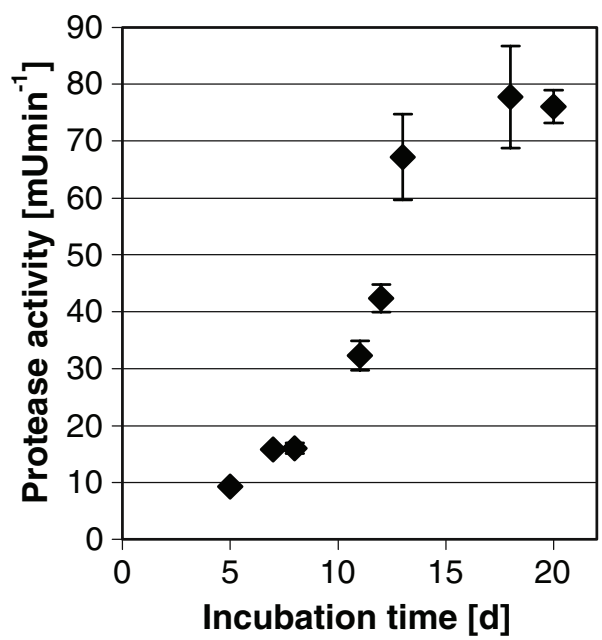

Fig. 1 Protease activity produced by B. brongniartii when grown on wool matography turned out to be superior to both other ion exchangers and hydrophobic interaction chromatography as first chromatographic separation step although further improvement of yields will be required (Table 1). In subsequent gel filtration chromatography only one dominant peak with protease activity was observed. In this peak, a single band was detected on SDS gels corresponding to a molecular weight of $27 \mathrm{kDa}$. This B. brongniartii wool protease had a $\mathrm{pI}$ value of 8.0 and was most active at $\mathrm{pH} 8.0$ and $20^{\circ} \mathrm{C}$. The half life times of the $B$. brongniartii protease at different conditions are shown in Table 2.

Although the enzyme showed little effects against various protease inhibitors, E-64, a cysteine inhibitor resulted in an $\mathrm{IC}_{50}$ value of $200 \mu \mathrm{M}$ at an incubation time of $2 \mathrm{~h}$. However, this rather small effect could also be due interaction with cysteine residues not involved in catalysis but e.g. in enzyme/substrate binding. Metal ions enhanced the stability of the protease, especially $\mathrm{Ca}^{2+}$ and $\mathrm{Mg}^{2+}$ increased the stability by $34 \%$ and $33 \%$, respectively at $5 \mathrm{mM}$ concentration. The optimum effect with $\mathrm{Ca}^{2+}$ was seen at $20 \mathrm{mM}$. Organic solvents also increased the stability of the $B$. brongniartii protease, shown for various alcohols (isopropanol, ethanol, methanol), DMF and DMSO. The enzyme hydrolysed the derivatized peptide substrates N-Suc-Ala-Ala-Pro-Phe- $p$ NA and N-Suc-Ala-Ala-Pro-Leu- $p$ NA and based on the catalytic efficiency obviously had a preference for the aromatic amino acid in the P1 position (Table 3). N-Suc-Ala-Ala-Pro-Phe- $p \mathrm{NA}$ is described as a specific substrate for chymotrypsin and subtilisin and N-Suc-Ala-Ala-Pro-Leu- $p$ NA can be cleaved by both elastase and chymotrypsin (Larcher et al. 1996). Both of these substrates are specific for serine proteases which is in contrast to the fact that the enzyme was slightly inhibited by E-64, known as cysteine protease inhibitor

Table 1 Purification of the B. brongniartii protease

\begin{tabular}{lllllll}
\hline & $\begin{array}{l}\text { Volume } \\
(\mathrm{ml})\end{array}$ & $\begin{array}{l}\text { Total } \\
\text { activity } \\
(\mathrm{U})\end{array}$ & $\begin{array}{l}\text { Yield } \\
\text { activity } \\
(\%)\end{array}$ & $\begin{array}{l}\text { Total } \\
\text { protein } \\
(\mathrm{mg})\end{array}$ & $\begin{array}{l}\text { Yield } \\
\text { protein } \\
(\%)\end{array}$ & $\begin{array}{l}\text { Specific } \\
\text { activity } \\
\left(\mathrm{U} \mathrm{mg}^{-1}\right)\end{array}$ \\
\hline Fermentation broth & 120 & 6.60 & 100 & 69.92 & $\begin{array}{l}\text { Fold of } \\
\text { purification }\end{array}$ \\
Concentration-VivaSpin & 10.25 & 6.34 & 96 & 38.03 & 54 & 0.09 \\
Cation exchange chromatography & 2.36 & 0.64 & 10 & 5.53 & 8 & 0.17 \\
Gel filtration chromatography & 9.20 & 0.35 & 5 & 2.12 & 3 & 0.59 \\
\hline
\end{tabular}


Table 2 Stability of the $B$. brongniartii protease at different conditions. Effect of different compounds and solvents were tested at $\mathrm{pH} 8$ and $20^{\circ} \mathrm{C}$

\begin{tabular}{|c|c|}
\hline Conditions & $\begin{array}{l}\text { Half life } \\
\text { time (h) }\end{array}$ \\
\hline $\mathrm{pH} 8^{*} 50^{\circ} \mathrm{C}$ & 2 \\
\hline $\mathrm{pH} 8^{*} 30^{\circ} \mathrm{C}$ & 25 \\
\hline $\mathrm{pH} 8^{*} 20^{\circ} \mathrm{C}$ & 33 \\
\hline $\mathrm{pH} 9 * 20^{\circ} \mathrm{C}$ & 20 \\
\hline $\mathrm{pH} 10^{*} 20^{\circ} \mathrm{C}$ & 13 \\
\hline $\mathrm{pH} 7 * 20^{\circ} \mathrm{C}$ & 24 \\
\hline $\mathrm{ACN}$ & 3 \\
\hline $\mathrm{MeOH}$ & 6 \\
\hline DMF & 10 \\
\hline DMSO & 19 \\
\hline $\mathrm{EtOH}$ & 24 \\
\hline Isopropanol & 31 \\
\hline $\mathrm{Ca}^{++}(5 \mathrm{mM})$ & 18 \\
\hline $\mathrm{Mg}^{++}(5 \mathrm{mM})$ & 18 \\
\hline $\mathrm{Zn}^{++}(5 \mathrm{mM})$ & 11 \\
\hline EDTA (5 mM) & 3 \\
\hline
\end{tabular}

*in the presence of $20 \mathrm{mM} \mathrm{CaCl}_{2}$

Table 3 Kinetic parameters of the B. brongniartii protease on selected substrates. No activity was detected on Gly-Phe- $p$ NA and L-Leu- $p$ NA

\begin{tabular}{llll}
\hline Substrate & $\begin{array}{l}\mathrm{K}_{\mathrm{m}} \\
(\mathrm{mM})\end{array}$ & $\begin{array}{l}\mathrm{K}_{\mathrm{cat}} \\
\left(\mathrm{s}^{-1}\right)\end{array}$ & $\mathrm{K}_{\mathrm{cat}} / \mathrm{K}_{\mathrm{m}}$ \\
\hline N-Suc-Ala-Ala-Pro-Phe- $p$ NA & 0.228 & 0.354 & 1.553 \\
N-Suc-Ala-Ala-Pro-Leu- $p$ NA & 0.202 & 0.056 & 0.277 \\
\hline
\end{tabular}

(Sigma). In contrast to other alkaline proteases, the $B$. brongniartii protease did not hydrolyse substrates with smaller chain length (Bakhtiar et al. 2005). No homology was found to existing enzymes with peptide mass mapping based on tryptic digestion and analysis of the peptide fragments with nano-HPLC-ESI-MS.

\section{Wool treatment}

Wool cuticle scales can be efficiently removed with both SDS and formic acid (Fig. 2). In contrast to formic acid, the SDS treatment allows better control with less damage to the whole fibres. Interestingly, the $\mathrm{C} / \mathrm{N}$ ratio of material released from wool during hydrolysis with the B. brongniartii protease increased with longer incubation times (Fig. 3). This might be due to the fact that the enzyme initially hydrolysed cuticles of the wool fibre. The dominant amino acid of cuticles is cysteine $(\mathrm{C} / \mathrm{N}=3)$ with a small $\mathrm{C}$-content compared to amino acids constituting proteins located more inside the fibre with a higher $\mathrm{C} / \mathrm{N}$ ratio $\mathrm{C} / \mathrm{N}_{\text {average }}=4.3$ which were obviously subsequently hydrolysed. The A-layer has the highest half-cysteine content with $37 \%$ and a high isopeptide amount (Zahn et al. 1997). Therefore, the $\mathrm{C} / \mathrm{N}$ ratio is small at the beginning and when the $B$. brongniartii protease has removed the cuticle material it starts to hydrolyze proteins in the cortex cells and cell membrane complex proteins until a plateau is reached after $32 \mathrm{~h}$.

The Bacillus protease shows a different behaviour. This enzyme seems to penetrate into the fibres from the beginning on. This results in a higher $\mathrm{C} / \mathrm{N}$ ratio of released material at the
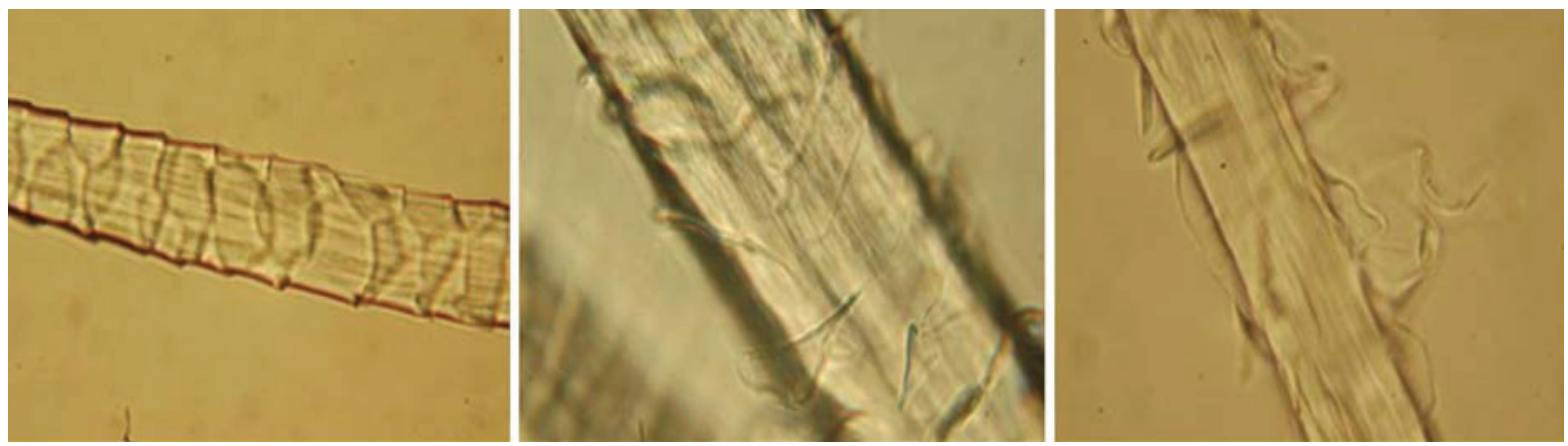

Fig. 2 Washed wool (left picture) compared to pre-treated wool (middle: wool pre-treated with SDS, right: wool pretreated with formic acid) 


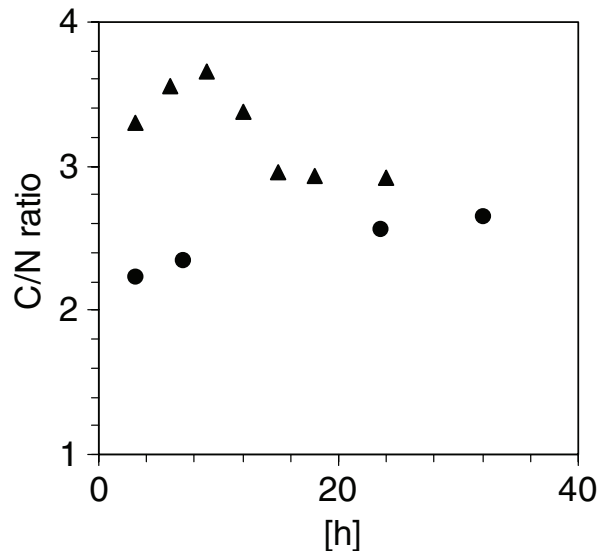

Fig. $3 \mathrm{C} / \mathrm{N}$ ratio of material released from wool by the B. brongniartii $(\bullet)$ and Bacillus sp. protease ( $(\mathbf{\Delta})$. All data result of four repetitions with a standard deviation of below $18 \%$

beginning compared to the B. brongniartii protease. When the reaction proceeds, cuticles (with high cysteine content) are also hydrolysed resulting in a decreasing $\mathrm{C} / \mathrm{N}$ ratio.

These results concerning the $\mathrm{C} / \mathrm{N}$ ratio of material released by the two different proteases correlate very well with the SEM pictures (Fig. 4). In contrast to the B. brongniartii protease, cracks (see arrows in Fig. 4) in the cuticle can clearly be seen after treatment with the Bacillus protease. This indicates that the enzyme was penetrating through the cuticle into the wool fibre and thereby destroying the fibre. Furthermore, treatments with the $B$. brongniartii protease lead to a smoother surface.

The substrate specificities of the two proteases were compared on wool and wool after partial removal of cuticles. Interestingly, the activity of the $B$. brongniartii protease decreases significantly with the removal of cuticles from wool while the activity of the Bacillus proteases remains the same (Fig. 5). These findings correlate both with the results of the $\mathrm{C} / \mathrm{N}$ measurements and microscopic observations indicating that the $B$. brongniartii protease preferentially hydrolyzes proteins of the cuticle scales.

\section{Conclusion}

The $\mathrm{C} / \mathrm{N}$ ratio of material released from wool after enzyme treatment can be used as an indication for the mode of action proteases on this substrate (on the surface or more inside the fibres). Together with other analytical methods (SEM, specificity on wool with removed cuticles) it was proven that the newly isolated protease from $B$. brongniartii preferentially hydrolysed wool cuticles when compared to a Bacillus sp. protease. Thus, this enzyme has a potential for wool anti-shrinkage treatment.
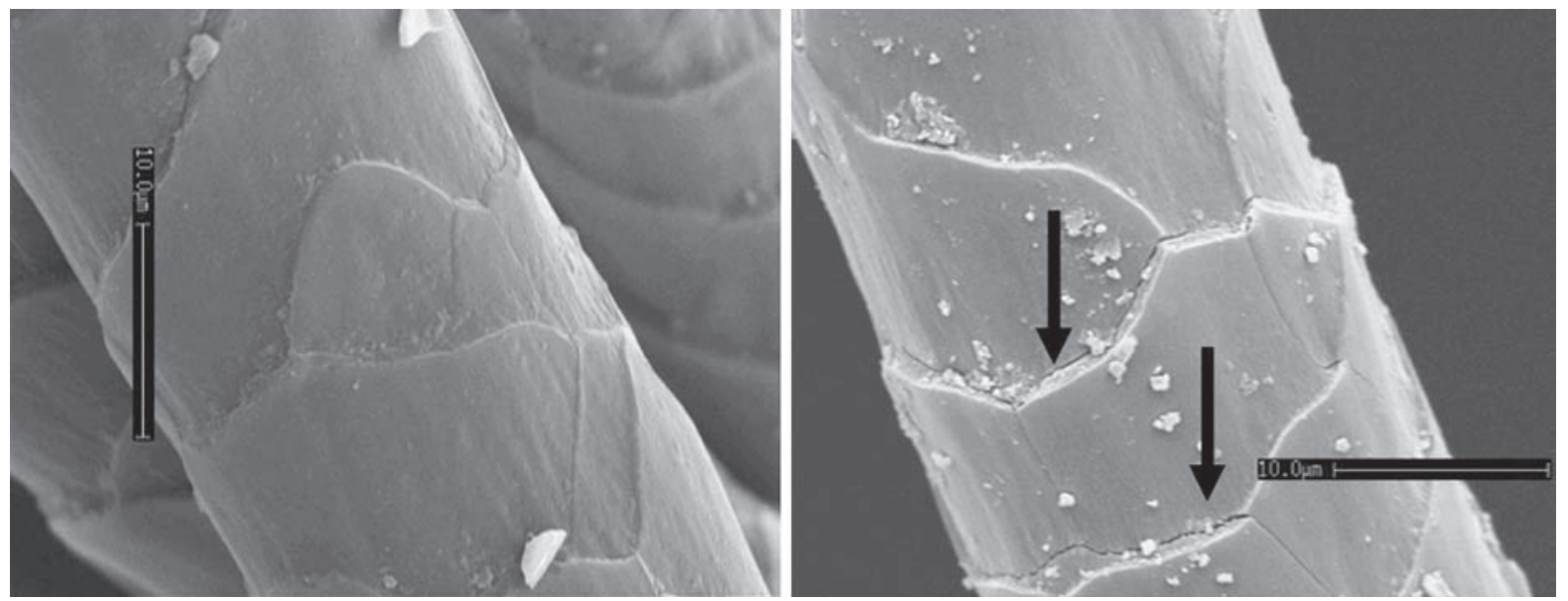

Fig. 4 SEM images of wool fibres treated $(30 \mathrm{~min})$ with the B. brongniartii protease (left picture) and the Bacillus $\mathrm{sp}$. protease (right picture) 
Fig. 5 Release of protein from wool and wool (W) with partially removed cuticles (W-) by the $B$. brongniartii protease and Bacillus sp. proteases. Cuticles were removed by SDS treatment. All data result of four repetitions

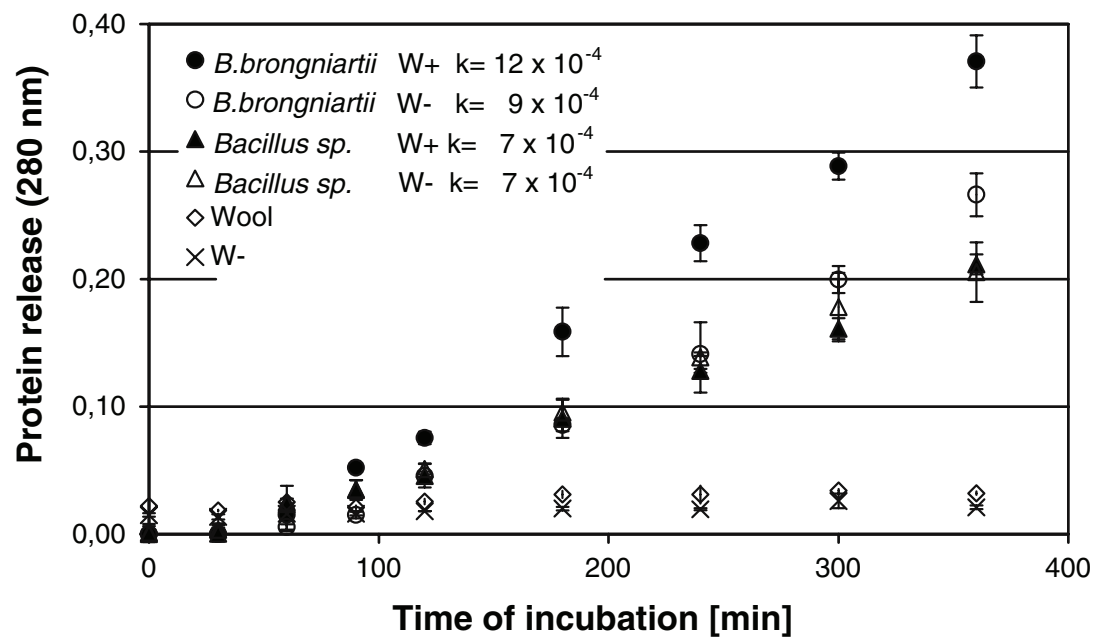

\section{References}

Bakhtiar S, Estiveira RJ, Hatti-Kaul R (2005) Substrate specificity of alkaline proteases from alkalophilic feather-degrading Nesterenkonia sp AL20. Enzyme Microb Technol 37:534-540

El-Sayed H, Kantouch A, Heine E, Höcker H (2001) Developing a zero-AOX shrink-resist process for wool, I: preliminary results. Color Technol 117:234238

Heine E, Höcker H (1995) Enzyme treatments for wool and cotton. Rev Prog Col 25:57-63

Higuchi T, Saika T, Senda S, Mizobata T, Kawata Y, Nagai Y (1997) Development of biorational pest control formulation against longicorn beetles using a fungus, Beauveria brongniartii (Sacc.) Petch. J Ferment Bioeng 84(3):236-243

Jovancic P, Jocic D, Molina R, Julia MR, Erra P (2001) Shrinkage properties of peroxide-enzmye-biopolymer treated wool. Text Res J 71(11):948-953

Jovancic P, Jocic D, Molina R, Julia MR, Erra P (2003) The combined low-temperature, plasma/enzyme wool shrink/resist treatment. AATCC Rev 3(2):25-28

Koller R, Jung K, Scheu S, Zimmermann G, Ruther J (2005) Biocontrol of the forest cockchafer (Melolontha hippocastani): experiments on the applicability of the "catch and infect"-technique using a combination of attractant traps with the entomopathogenic fungus Beauveria brongniartii, insect pathogens and insect parasitic nematodes: melolonatha. IOBC/WPRS Bull 28(2):37-44

Larcher G, Cimon B, Symoens, Tronchin G, Chabasse D, Bouchara JP (1996) A $33 \mathrm{kDa}$ serine proteinase from Scedosporium apiospermum. Biochem J 315:119-126

Schroeder M, Schweitzer M, Lenting HBM, Guebitz GM (2004) Chemical modification of proteases for wool cuticle scale removal. Biocat Biotrans 22(5/6):299-305

Sousa F, Cavaco-Paulo A, Erlacher A, Schroeder M, Guebitz GM (2005) Novel bacterial and modified proteases for wool treatment COST847 Congr Text Biotechnol Maspalomas, Spain Feb. 20-23

Shevchenko A, Wilm M, Vorm O, Mann M (1996) Mass spectrometric sequencing of protein-silver-stained polyacrylamide gels. Anal Chem 68(5):850-858

Simpson WS, Crawshaw GH (2002) Wool: science and technology. CRC Press, Boca Raton ISBN 08493 28209

Zahn H, Hoffmann R (1996) "Wool" in Ullmann's Encyclopedia of Industrial Chemistry, Vol. A 28, VCH Verlagsgesellschaft. Weinheim, Germany, ISBN 3527201289

Zahn H, Wortmann FJ, Höcker H (1997) Chemie und Aufbau der Wolle, Chemie in unserer Zeit, WileyVCH, Nr. 6 